The BDJ News section accepts items that include general news, latest research and diary events that interest our readers. Press releases or articles may be edited, and should include a colour photograph if possible. Please direct your correspondence to the News Editor, Arveen Bajaj at the BDJ, The Macmillan Building, 4 Crinan Street, London N19XW or by email to bdj@bda.org

\section{First oral health forum in Rwanda}

The World Health Organisation (WHO (AFRO) and the FDI World Dental Federation jointly organised a forum which brought together members of the dental profession, government officials, and oral health and policy experts in Rwanda recently. The Health Minister of Rwanda, Dr Jean Damascène Ntawukuliryayo, opened the first ever high-level forum on oral health in the country.

The two-day workshop came up with recommendations to address the oral health challenges of Rwanda where the dentist-population ratio is less than $1: 800,000$, and the distance people have to travel to get dental care is on average 300 $\mathrm{km}$. Two thirds of the population have no access to oral health care at all.

The meeting was also a sequel to the international conference on oral health in the African Region jointly organised by the FDI World Dental Federation and WHO in April 2004 in Nairobi, Kenya. That conference adopted the landmark Nairobi Declaration on Oral Health, the highlights of which include emphasis on appropriate oral health programmes in Africa, a commitment to general and oral health as a basic human right as well as the need for the integration of oral health within general health programmes.

\section{New PCD School opened}

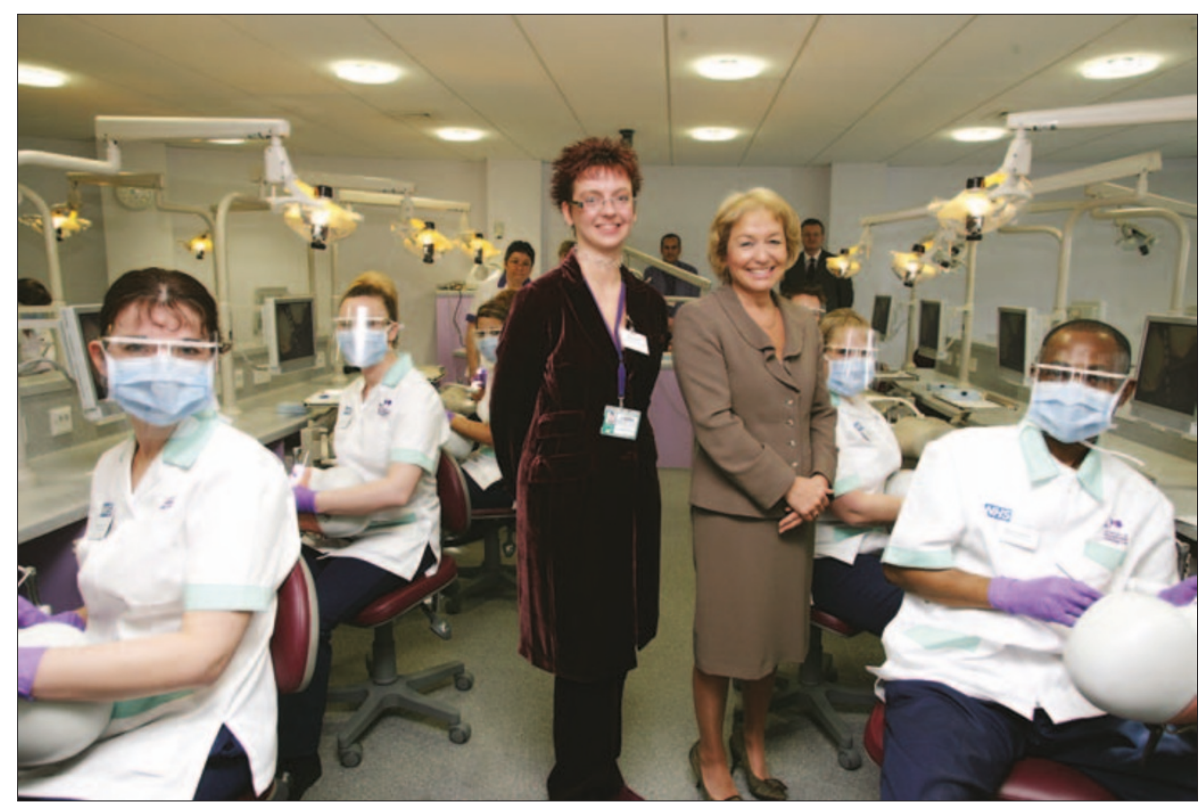

The University of Portsmouth's new School of Professionals Complementary to Dentistry was opened recently by Health Minister Rosie Winterton. The new school, named after William Beatty, Lord Nelson's surgeon and dentist on-board the HMS Victory at the Battle of Trafalgar, is housed in a $€ 4 \mathrm{~m}$ purpose built building and includes a 24-bay treatment clinic, two private surgeries, a phantom head room and a radiography suite. It is the first of its kind in the country and offers a range of courses in response to the national shortage of dental professionals. Graduates of the BSc programme will be qualified to work alongside registered dentists as dental hygienists or dental therapists. They will be able to perform duties such as administering dental local anaesthetics, extracting children's teeth, provide simple fillings, take radiographs, scale and polish teeth and deliver oral health education. Pictured above, Sara Holmes, Head of the School of Professionals Complementary to Dentistry (left) with Health Minister Rosie Winterton and students at the School. For further information contact Carol Gough on 02392843946.

\title{
Predicting caries
}

A simple saliva test can predict for the first time whether children will get cavities, how many cavities they will get and even which teeth are most vulnerable, researchers from the University of Southern California (USC) claim.

Developed by a USC School of Dentistry team led by professor Paul Denny, the test quantifies the genetic component of caries.

The Caries Assessment and Risk Evaluation (CARE) test measures the relative proportions in saliva of different types of sugar chains, known as oligosaccharides. The same sugar chains are present on tooth surfaces.

A different version of the test identifies the particular teeth at risk, Denny said. And the test's specificity may reduce the cost and increase the effectiveness of prevention.

"It's possible that in the future - even though a kid might be at very high risk for getting a large number of caries - with the proper preventive measures he (or she) can arrive at adulthood without any," Denny said. A further version of the test can identify children with active tooth decay.

The research was supported by a grant from the National Institute of Dental and Craniofacial Research, part of the National Institutes of Health.

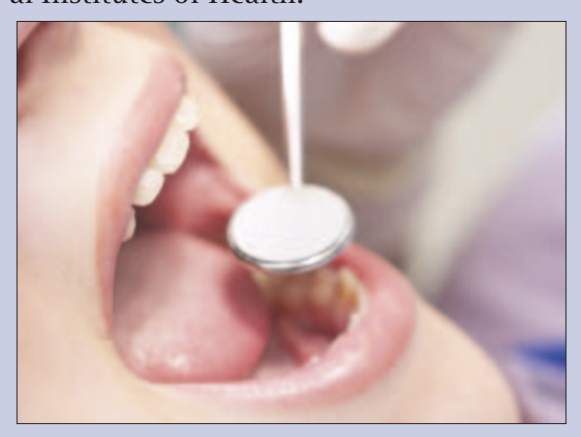




\section{DIARY}

April 2005

Academy of Laser Dentistry Source 2005:

Lasers in Dentistry

Date: 6-9.04.05

Venue: New Orleans Marriott Hotel, New

Orleans, Louisiana, USA

Tel: 1-877-527-3776

Email: memberservices@laserdentistry.org www.source2005.org

Dental Sedation Teachers' Group Annual

Symposium 2005

Date: 26.04 .05

Venue: The Royal College of Physicians and Surgeons, London

Tel: +44 (0) 1412216072

Fax: +44 (0) 1412211804

Email:n.d.robb@dental.gla.ac.uk

www.dstg.co.uk

Irish Dental Association Annual Scientific Conference

Date: 14-16.04.05

Venue: Killarney, Ireland

Tel: 0035312830499

Email:info@irishdentalass.ie

IDS International Dental Show

Date: 12-16.04.05

Venue: Cologne

Tel: +44 01604 - 621014

Fax: +4408709909523

Email: tradefairs@yorks-travel.co.uk www.idfdentalconference.com

FGDP UK \& FDS Dentists with a Special Interest Date: 21.04 .05

Venue: The Royal College of Surgeons of England, London

Tel: +44 (0) 2078696758 / 6768

Email:fgdp@rcseng.ac.uk

www.rcseng.ac.uk/fgdp

May 2005

The Association of Dental Implantology

(ADI) 2005 International Congress

Date: 12-14.05.05

Venue: Edinburgh International Congress Centre

Tel: +44 (0) 2084875555

Fax: +44 (0) 2084875566

Email: adi.uk@btinternet.com www.adi.org.uk

The BDA 2005 British Dental Conference and Exhibition

Date: 19-21.05.05

Venue: Scottish Exhibition and

Conference Centre (SECC), Glasgow

Tel: 08701666625

Email: events@bda.org

www.bda-events.org

\section{Rebuilding faces}

Surgeons are using a revolutionary implant to help rebuild the faces of children injured in accidents or born with serious defects.

Scientists from The University of Nottingham have teamed up with Russian researchers to create the honeycomb-like polymer which readily bonds with bone without causing adverse reactions. It is currently undergoing clinical trials in Moscow where it has been used on around fifty children aged from eighteen months to 18 years.

Among the patients who have undergone surgery are a baby with a jaw tumour and a twelve-year-old girl who had been barely able to open her mouth from birth.

The 'PolyHap' implants have been developed by teams led by Professor Steve Howdle at The University of Nottingham, and Dr Vladimir Popov from the Institute of Laser and Information Technology in Troitsk, near Moscow with funding provided by the Wellcome Trust.

Professor Howdle, of The University of Nottingham's School of Chemistry, said: "Precision is vital in this type of operation since every injury will be unique in some way and the patient is obviously hoping for the best possible visual affect after surgery."

So far the Moscow operations have been carried out to correct jaw or skull deformities. But the implants can be adapted for any part of the skeleton. Professor Vitaly Roginsky, one of Russia's leading children's cranio-maxillofacial surgeons, said: "These implants allow us to carry out many more operations than before. They are easier to adjust and re-shape and give us much more flexibility in our work."

Although the PolyHap implants have produced good results there is a possibility they might have to be replaced as the child grows and bones develop. So Professor Howdle and Dr Popov's teams have started work on a bio-degradeable version which will slowly dissolve as the repairing bone begins to re-grow.

Professor John Lowry, Secretary General of the European Association for Cranio-Maxillofacial Surgery, said: "The technique being developed through this collaboration has some interesting innovations and once perfected or even further developed it should prove a great help to surgeons involved in this complex area of surgery."
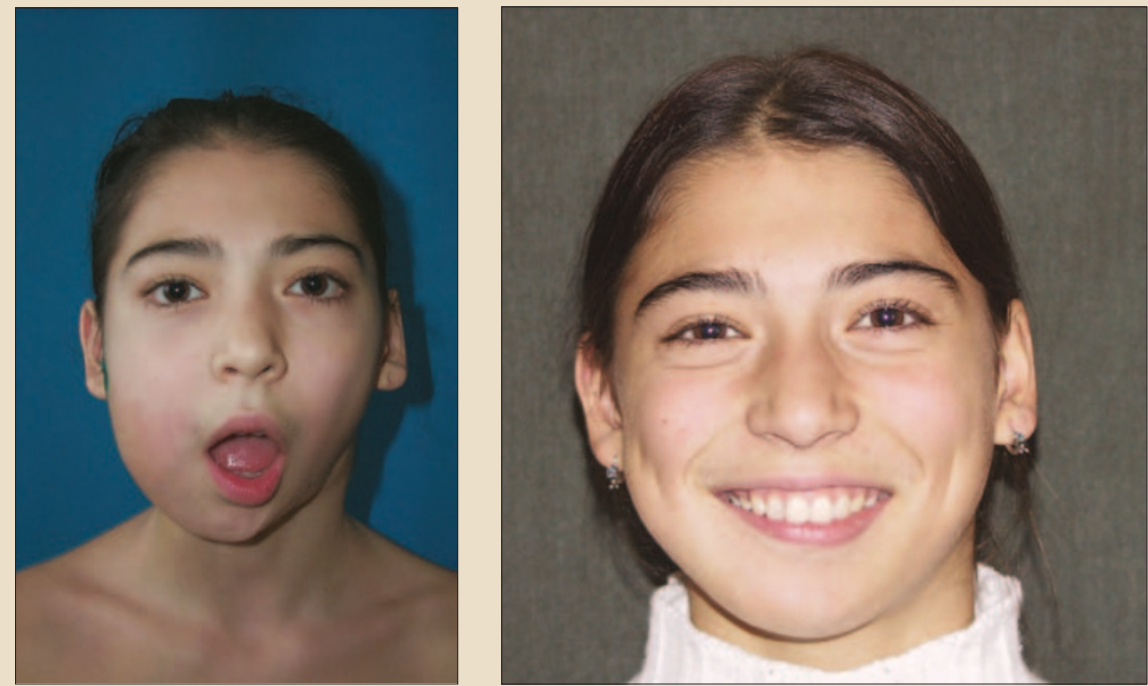

Anara Djantemiroma before and after the operation

\section{Legislation delayed}

New legislation, which will enable the General Dental Council (GDC) to start registering new groups of professionals complementary to dentistry (PCDs) and set up a new Private Patient Complaints Scheme has been further delayed, the Government has announced.

The legislative process, which was originally time-tabled for completion in January 2005 and has been subject to a number of delays, is now expected to be completed in the summer, and the GDC says that its initiatives will be put back to 2006.

It adds that it is disappointed by this news and has made strong representations to the Department of Health to try to ensure there will be no further delay. 


\section{Brushing teeth for all round health}

People who brush their teeth more often stay slimmer, according to a recent Japanese study. In a survey of the everyday habits of nearly 14,000 people whose average age was in their mid-40s, Dr Takashi Wada of Jikei University in Tokyo found that those who managed to stay slim tended to brush their teeth after every meal.

The study, published in the Journal of the Japan Society for the Study of Obesity found that overweight men sometimes went more than a day without brushing their teeth.

Dr Wada and his team compared the lifestyles of people whose body mass index (BMI) was over 25 - the level doctors define as overweight - with those of slimmer people. The survey covered eating and drinking habits, sleep, work and exercise.

The results do not mean that brushing in itself constitutes a fat-burning exercise, the authors say. "It's a sign that these people are careful about their health - they want to maintain the appearance of their teeth and prevent bad breath," the paper said. "We think actively encouraging the habit of toothbrushing would play a role in maintaining health and would help prevent obesity."

Meanwhile a separate study has reported that brushing your teeth could reduce the risk of having a stroke or heart attack.

A team from Columbia University found people with gum disease were more likely to suffer from atherosclerosis - a narrowing of blood vessels, a condition that can precede a stroke or heart attack.

Published in the journal Circulation, researchers looked at levels of bacteria in the mouths of 657 people who had no history of stroke or myocardial infarction (heart attack). The researchers also measured the thickness of the subjects' carotid artery, which carries blood from the heart to the brain, and which is measured to identify atherosclerosis.

It was found that those people who had a higher level of the specific bacteria that causes periodontal disease also had an increased carotid artery thickness, even after taking other cardiovascular risk factors into account.

The team also found that the link with atherosclerosis only existed for the bacteria which was known to cause gum disease, and not other bacteria found in the mouth.

The British Heart Foundation welcomed the study but said it would encourage people to follow a healthy lifestyle to reduce their risk of heart disease.

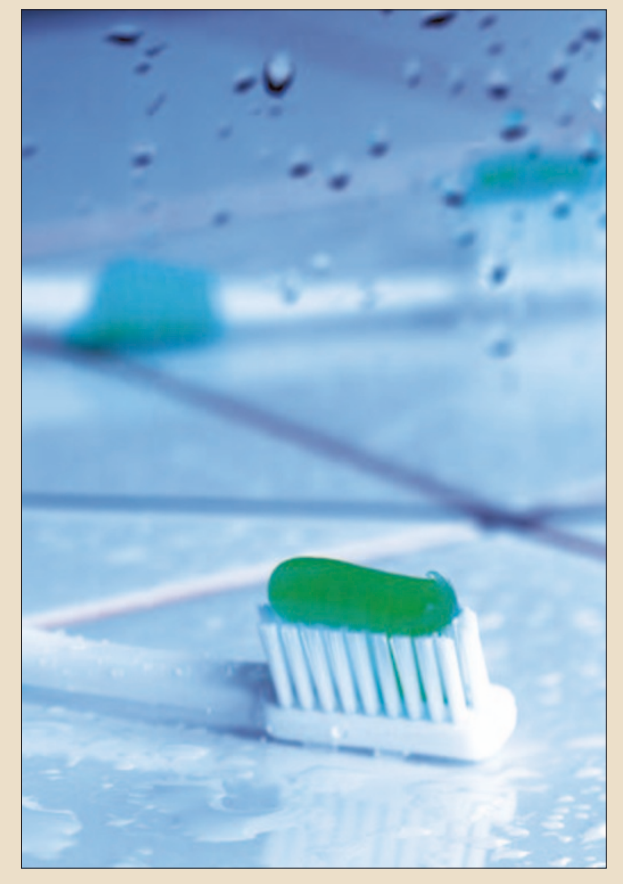

\section{Search for tsunami dentist}

A family from Canada is searching for a London dentist who came to the aid of survivors of the tsunami disaster that hit Asia last December.

Alejandra and Mark Perry, 21 year old daughter Melissa Perry, 20 year old son Lyle Perry and their friend, 22 year old Paul Ladner together with the male dentist known only as Bob started to administer first aid to the injured on Phi Phi Island, Thailand, in an area called Viewpoint on the east side of the Island.

Bob, Melissa, Paul and Lyle became the 'first aid' center for many hundreds of injured people. He is a dentist from London, said to have been travelling with his wife possibly in his thirties, light medium build, of dark complexion and eyes, possibly of Indian descent and around 5'10" in height.

The family say that Bob made a big difference and provided moral support for the three young Canadians, hence their search. Please contact the BDJ on 02078433679 or email a.bajaj@nature.com if you have any information. 